\title{
Thermal performance of a dome-covered house
}

\author{
Y. Lin \& R. Zmeureanu \\ Centre for Building Studies, \\ Department of Building, Civil and Environmental Engineering, \\ Faculty of Engineering and Computer Science, Concordia University, \\ Montreal, Canada
}

\begin{abstract}
A dome-covered house is an example of designing sustainable buildings by learning from the optimized biological forms from nature. This paper presents the mathematical model for estimating the energy performance of the ensemble dome-house. The heat balance equations are written at the dome surface, for the air inside the dome, at the outside surfaces of the house, at the inside surfaces of the house, at the ground surfaces, and for the air inside the house. The annual energy performance of the dome-covered house is presented and compared with that of an isolated house located in Yellowknife (Canada) at $61^{\circ} \mathrm{N}$ latitude.

Keywords: energy performance, dome-covered house, optimized biological form, mathematical model.
\end{abstract}

\section{Introduction}

Dome structure is based on self-generating forms in nature, bubble clusters being typical examples. It is based on the natural form-optimizing process in biological structures and can be translated into the architectural world in the form of pneumatic structure $[1,2]$. The dome configuration applies nature's principles of forming a highly efficient system. The advantages of designing a dome-covered house in Canada are [3]: it can provide a shelter to withstand high winds and extreme temperatures in northern part of Canada; it can store large amounts of solar radiation and thus reduce the heating load of the covered house in the winter; and it can provide pleasant view without sense of enclosure if the dome is transparent or translucent.

Examples of dome structures in nature are the sunflower, the shell of sea urchin, and the rose bubble shell. The dome-like shape of the sunflower enables 
it to receive maximum solar radiation during daytime. The dome-like shapes of the sea urchin and the rose bubble shell enable them to overcome the water pressure.

More attention has been given to the structural configurations than on the thermal performance of dome-like buildings. According to the Buckminster Fuller Institute [4], some of the largest geodesic-dome structures (listed in descending order from largest diameter) are presented in Table 1:

Table 1: The largest geodesic-dome structures.

\begin{tabular}{llll}
\hline No. & Name & Location & Diameter (m) \\
\hline 1 & Fantasy Entertainment & Kyosho Isle, Japan & 216 \\
& Complex & & \\
2 & Multi-Purpose Arena & Nagoya, Japan & 187 \\
3 & Tacoma Dome & Tacoma, WA, USA & 161 \\
4 & Superior Dome & $\begin{array}{l}\text { Northern Michigan Univ } \\
\text { Marquette, MI, USA }\end{array}$ & \\
5 & Walkup Skydome & $\begin{array}{l}\text { Northern Arizona Univ. } \\
\text { Flagstaff, AZ, USA }\end{array}$ \\
& & Fla \\
\hline
\end{tabular}

According to Monolithic Dome Institute [5], a monolithic dome home has approximately $333 \mathrm{~m}^{2}$ of living space, walls and ceiling with thermal resistances of $10.5 \mathrm{~m}^{2} \cdot \mathrm{K} / \mathrm{W}$, low emissive windows and low flow water fixtures. The owner obtained energy savings of over $\$ 2000$ per year compared to a conventional masonry house of the same size. Croome [3] presented his concept of building a covered township in the northern part of Canada. In his studies, the dome structure was composed of double layer membrane material. The simulation results predicted a $15.7 \%$ reduction of the annual heating energy consumption for houses built under that cover, compared with houses without cover.

Transparent and translucent domes have been used as skylights for daylighting and energy saving purposes. Some models [6-9] have been developed to predict the optical and thermal properties of the dome skylight. Those models replaced single-glazed hemispherical dome skylights by optically and thermally equivalent single-glazed planar skylights. Smith [10] developed a mathematical model to predict the impact of thermal exchange within pyranometers, simulated as a small glass dome, considering only convection and conduction. Electrochromic glazing may be used to prevent the overheating inside such structure in the summer. For instance, Porta-Gándara \& GómezMuñoz [11] modeled a Fuller type geodesic dome to estimate the solar energy that passes through the dome, when it is covered with electrochromic glazing, compared with the case of a common glass.

\section{Mathematical model}

\subsection{Heat balance of the dome glazing}

The dome surface is divided into 84 rows and 26 columns that give 2184 cells (Figure 1). The heat balance equation at the center of each cell $(\mathrm{i}, \mathrm{j})$ is written as: 


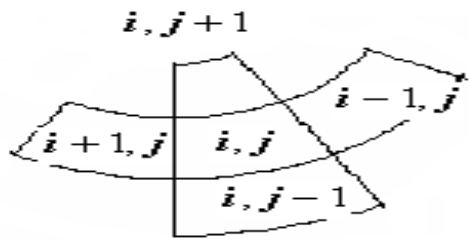

Figure 1: Adjacent cells.

$$
\begin{aligned}
& k d l_{i+1, j}\left(T_{i+1, j}-T_{i, j}\right)+k d l_{i-1, j}\left(T_{i-1, j}-T_{i, j}\right) \\
& +k d l_{i, j-1}\left(T_{i, j-1}-T_{i, j}\right) k d l_{i, j+1}\left(T_{i, j+1}-T_{i, j}\right) \\
& +\left(q_{\text {sol }, i j}+q_{\text {conv }, i j}+q_{L W R, i j}+q_{\text {surf }, i j}\right) A_{i j}=m_{i j} c_{p} \frac{d T}{d t}
\end{aligned}
$$

where $\mathrm{q}_{\mathrm{sol}, \mathrm{jj}}=$ the absorbed incident solar radiation, in $\mathrm{W} / \mathrm{m}^{2} ; \mathrm{q}_{\mathrm{conv}, \mathrm{ij}}=$ the convective heat flux over the inside and outside cell surfaces, in $\mathrm{W} / \mathrm{m}^{2} ; \mathrm{q}_{L W R, \mathrm{ij}}=$ the long wave radiation with the outdoor environment (ground and sky), in $\mathrm{W} / \mathrm{m}^{2} ; \mathrm{q}_{\text {surf }, \text { ij }}=$ the net long-wave surface-to-surface radiation between the cell and other surfaces inside the dome, in $\mathrm{W} / \mathrm{m}^{2} ; \mathrm{m}_{\mathrm{ij}}=$ the mass of cell $(\mathrm{i}, \mathrm{j})$, in $\mathrm{kg} ; \mathrm{c}_{\mathrm{p}}=$ specific heat of the dome glazing, in $\mathrm{J} / \mathrm{kg} \cdot{ }^{\circ} \mathrm{C} ; \mathrm{T}=$ temperature, in ${ }^{\circ} \mathrm{C} ; \mathrm{t}=$ time, in sec, $\mathrm{k}=$ conductivity of the glazing, in $\mathrm{W} / \mathrm{m}-\mathrm{K} ; \mathrm{d}=$ thickness of the glazing, in $\mathrm{m}, \mathrm{l}=$ length of the interface between two adjacent cells, in $\mathrm{m}$.

\subsection{Heat balance of the air inside the dome}

The indoor air is assumed well mixed and therefore it is represented by one node. The heat balance equation for the air inside the dome is written as:

$$
Q_{\text {conv }, \text { in }}+Q_{\mathrm{inf}}+Q_{\text {exf }}=m_{i n} c_{p} \frac{d T}{d t}
$$

where $\mathrm{Q}_{\text {conv,in }}=$ the convective heat flux over all inside surfaces, in $\mathrm{W} ; \mathrm{Q}_{\text {inf }}=$ the infiltration heat gain/loss due to the outside air, in $\mathrm{W} ; \mathrm{Q}_{\mathrm{exf}}=$ the exfiltration heat gain/loss from the air inside the house, in $\mathrm{W} ; \mathrm{m}_{\mathrm{in}}=$ the mass of air inside the dome, in $\mathrm{kg} ; \mathrm{c}_{\mathrm{p}}=$ specific heat of air inside the dome, in $\mathrm{J} / \mathrm{kg} \cdot{ }^{\circ} \mathrm{C}$.

\subsection{Heat transfer through walls}

Each exterior wall of the house inside the dome is assumed to have four layers. Nine nodes are used to discretize each wall/roof. The governing equation for the one dimensional heat transfer process in each layer is written as follows:

$$
\frac{\partial T}{\partial t}=\alpha \frac{\partial T^{2}}{\partial x^{2}}
$$

where $\alpha=$ the thermal diffusivity of each layer of the wall, in $\mathrm{m}^{2} / \mathrm{s} ; \mathrm{x}=$ thickness of the layer, in $\mathrm{m}$. 
The outside boundary conditions can be written as follows:

$$
-\left.k_{1} \frac{\partial T}{\partial x}\right|_{x=0}+q_{\text {sol }, l, \text { out }}+q_{\text {conv }, l, \text { out }}+q_{\text {surf }, l, \text { out }}=\rho_{1} * \frac{1}{2} d x_{1} * c_{p 1} * \frac{d T}{d t}
$$

where $\mathrm{k}_{1}=$ thermal conductivity of the first layer of the wall/roof, W/m-K; $\mathrm{q}_{\text {sol,out }}=$ the absorbed solar radiation that is received at the outside wall surface, $\mathrm{W} / \mathrm{m}^{2} ; \mathrm{q}_{\mathrm{conv}, \mathrm{out}}=$ the convective heat transfer over the outside wall surface, $\mathrm{W} / \mathrm{m}^{2}$; $\mathrm{q}_{\text {surfout }}=$ the net surface-to-surface radiation leaving the outside wall surface, $\mathrm{W} / \mathrm{m}^{2} ; \rho_{1}=$ density of the first layer of the wall, $\mathrm{kg} / \mathrm{m}^{3} ; \mathrm{dx}_{1}=$ thickness of the first layer of the wall, $\mathrm{m} ; \mathrm{c}_{\mathrm{p} 1}=$ specific heat of the first layer of the wall, $\mathrm{J} / \mathrm{kg} \cdot{ }^{\circ} \mathrm{C}$.

The inside boundary conditions can be written as follows:

$$
-\left.k_{4} \frac{\partial T}{\partial x}\right|_{x=t h}+q_{\text {conv }, \text {, in }}+q_{\text {surf }, \text {, in }}+q_{\text {rad }, \text { ing }}=\rho_{4} * \frac{1}{2} d x_{4} * c_{p 4} * \frac{d T}{d t}
$$

where $\mathrm{k}=$ thermal conductivity of the last layer, $\mathrm{W} / \mathrm{m}-\mathrm{K} ; \mathrm{q}_{\text {conv, }, \mathrm{in}}=$ the convective heat transfer over the inside wall surface, $\mathrm{W} / \mathrm{m}^{2} ; \mathrm{q}_{\text {surf, }, \text { in }}=$ the net surface-to-surface radiation leaving the inside wall surface, $\mathrm{W} / \mathrm{m}^{2} ; \mathrm{q}_{\mathrm{rad}, \text { ing, },}=$ the radiation heat flux due to internal heat gain, $\mathrm{W} / \mathrm{m}^{2} ; \mathrm{dx}_{4}=$ thickness of the last layer, in $\mathrm{m}$.

\subsection{Heat transfer through the ground inside the dome}

The one-dimensional heat transfer equation (3) is applied. The outside boundary conditions can be written in similar way as equation (4). The temperature of undisturbed ground at $3.0 \mathrm{~m}$ is assumed to be equal to the soil temperature obtained from Energyplus [12]. A number of nine layers are used to discretize the ground on the vertical direction.

\subsection{Heat balance of the house indoor air}

The air inside the house is assumed well mixed and therefore it is represented by one node. The indoor air temperature $T_{a}$ is held at the set-point value by a heating, ventilation and air-conditioning (HVAC) system. The heat balance for the indoor air is written as:

$$
Q_{H V A C}+\sum_{j=1}^{6} A_{j} h_{a}\left(T_{j, \text { in }}-T_{a}\right)+Q_{\text {inf }}+Q_{\text {int ernal }, \text { conv }}=0
$$

where $T_{j, \text { in }}=$ the inside surface temperature of the jth wall, window, roof or floor, in ${ }^{\circ} \mathrm{C} ; \mathrm{Q}_{\mathrm{HVAC}}=$ the heat extraction/addition rate by the HVAC system, in $\mathrm{W}$; $Q_{i n f}=$ the infiltration heat gain/loss due to the air inside the dome, in W; $\mathrm{Q}_{\text {internal,conv }}=$ the convective part of internal heat gain, in $\mathrm{W} ; \mathrm{T}_{\mathrm{a}}=$ room air temperature (e.g., $\mathrm{T}=20^{\circ} \mathrm{C}$ ).

\subsection{Inside convection coefficient}

The inside convection coefficient for each dome cell is calculated by assuming natural convection [13]: 


$$
\begin{aligned}
& h_{n}=9.482 \cdot \frac{\sqrt[3]{|\Delta T|}}{7.238-|\cos \Sigma|} \text { (for upward heat flow) } \\
& h_{n}=1.810 \cdot \frac{\sqrt[3]{|\Delta T|}}{1.382+|\cos \Sigma|} \text { (for downward flow) }
\end{aligned}
$$

where $\Delta \mathrm{T}=$ the temperature difference between surface and air, ${ }^{\circ} \mathrm{C} ; \Sigma=$ the tilted angle of surface, degree.

\subsection{Outside convection coefficient}

The outside convection coefficient is calculated as follows [14]:

$$
h_{o}=\sqrt{h_{n}^{2}+\left[a V_{a z}^{b}\right]^{2}}
$$

where $h_{o}=$ the outside convection coefficient, in $\mathrm{W} / \mathrm{m}^{2} \cdot{ }^{\circ} \mathrm{C} ; \mathrm{h}_{\mathrm{n}}=$ the natural component of convection coefficient, in $\mathrm{W} / \mathrm{m}^{2} \cdot{ }^{\circ} \mathrm{C} ; \mathrm{V}_{\mathrm{az}}=$ the wind speed over the surface, in $\mathrm{m} / \mathrm{s}$.

\subsection{Radiation coefficient}

The net radiation exchange of a surface is equal to the difference between the surface radiosity and irradiation. The total long-wave incident radiation of surface $A_{j}$ is:

$$
A_{j} \frac{J_{j}-\varepsilon_{j} E_{j}}{\rho_{j}}=\sum_{i=1}^{N_{\text {suffaces }}} J_{i} F_{i j} A_{i}
$$

where $\varepsilon=$ the emmissivity of each surface, $J=$ the radiosity of each surface, $\mathrm{W} / \mathrm{m}^{2}, \mathrm{E}_{\mathrm{j}}=$ the blackbody emissivity power, $\mathrm{W} / \mathrm{m}^{2}, \mathrm{~F}_{\mathrm{ij}}=$ the view factor between two surface $i$ and $j$.

Hotel and Sarofim [15] simplified the calculation of the radiant exchange calculation by pre-calculating all geometry and surface-related properties using a total gray interchange area, $\mathrm{S}_{\mathrm{ij}}$. By applying this concept, the net radiation exchange at one surface becomes a simple summation of all the incident radiations from other surfaces to the destination surface. With this method, the network equations can be solved once and used throughout the rest of the simulation period. In this paper, a new view factor based on the total interchange area is defined and used to calculate the long-wave radiation between inside surfaces. The total interchange view factors can be obtained by solving the systems of equations. With the total interchange view factor, the radiation coefficient between two surfaces $\mathrm{i}$ and $\mathrm{j}$ can then be written as:

$$
h_{r},{ }_{i j}=\sigma \cdot F_{i j}\left(T_{i}^{2}+T_{j}^{2}\right)\left(T_{i}+T_{j}\right)
$$

where $\sigma=$ Stephan-Boltzmann constant, $5.67 \times 10^{-8} \mathrm{~W} / \mathrm{m}_{2} \cdot \mathrm{K}^{4} ; \mathbf{F}_{\mathrm{ij}}=$ the total interchange view factor between surfaces $i$ and $j$. 


\section{Comparison with analytical model/experimental data}

\subsection{Comparison with a simplified analytical model}

A simplified case was used for preliminary verification of the computer model where the ground, wall and roof are assumed to be well insulated. No wind, sky radiation, longwave radiation between the dome and outdoor ground, and solar radiation is considered. A simplified mathematical model composed of three nodes, one for the air inside the dome, one for the ground inside the dome, and one for the glazing, is developed:

$$
\begin{gathered}
h_{i n} A_{\text {dome }}\left(T_{s}-T_{i n}\right)+h_{i n} A_{g}\left(T_{g}-T_{i n}\right)=m_{i n} c_{p, i n} \frac{d T_{i n}}{d t} \\
h_{r}\left(T_{s}-T_{g}\right)+h_{i n}\left(T_{i n}-T_{g}\right)=\frac{1}{2} \rho_{g} d x c_{p, g} \frac{d T_{g}}{d t} \\
h_{o}\left(T_{o}-T_{s}\right)+h_{i n}\left(T_{i n}-T_{s}\right)+h_{r}\left(T_{g}-T_{s}\right)=\rho_{s} d_{s} \frac{d T_{s}}{d t}
\end{gathered}
$$

where $h_{\text {in }}$ is the convection coefficient over the inside surface of dome; $A_{\text {dome }}$ is the area of the dome surface; $T_{s}$ is the glazing temperature; $T_{\text {in }}$ is the air temperature inside the dome; $\mathrm{A}_{\mathrm{g}}$ is the area of the ground; $\mathrm{T}_{\mathrm{g}}$ is the temperature of the ground surface; $m_{i n}$ is the mass of the air inside the dome; $c_{p, \text { in }}$ is the specific heat of air; $h_{r}$ is the radiation coefficient; $\rho_{g}$ is the density of soil; $d x$ is the thickness of ground layer; $c_{p, g}$ is the specific heat of soil; $h_{o}$ is the convection coefficient over the outside surface of dome; $\rho_{\mathrm{s}}$ is the density of the glazing; and $\mathrm{d}_{\mathrm{s}}$ is the thickness of glazing.

The solution of equations (12-14) is obtained in the MATLAB environment. Initially, all temperatures are assumed to be equal to $\left(-10^{\circ} \mathrm{C}\right)$. Then, the outdoor air temperature rises suddenly to $0^{\circ} \mathrm{C}$. The variation of air temperature inside the dome under this step change of outdoor air temperature, as estimated by the detailed computer model and by the simplified model, is presented in Figure 2. The results indicate a good agreement between the two models, as the maximum difference is less than $0.7^{\circ} \mathrm{C}$. The three temperatures converge to the outdoor air temperature of $0^{\circ} \mathrm{C}$ after about 17 hours.

\subsection{Comparison with experimental data}

The simulation results are compared with the experimental data of two cases as presented by Smith [10] (Figure 3 and Figure 4). In the first case, the temperature of dome and of air inside the dome is assumed to be equal to $0^{\circ} \mathrm{C}$ initially. Then, the outdoor air temperature rises suddenly to $19.25^{\circ} \mathrm{C}$. In the second case, the initial temperature is $\left(-4.65^{\circ} \mathrm{C}\right)$ and the final temperature is $22.85^{\circ} \mathrm{C}$. The simulation results agree well with experimental data. 


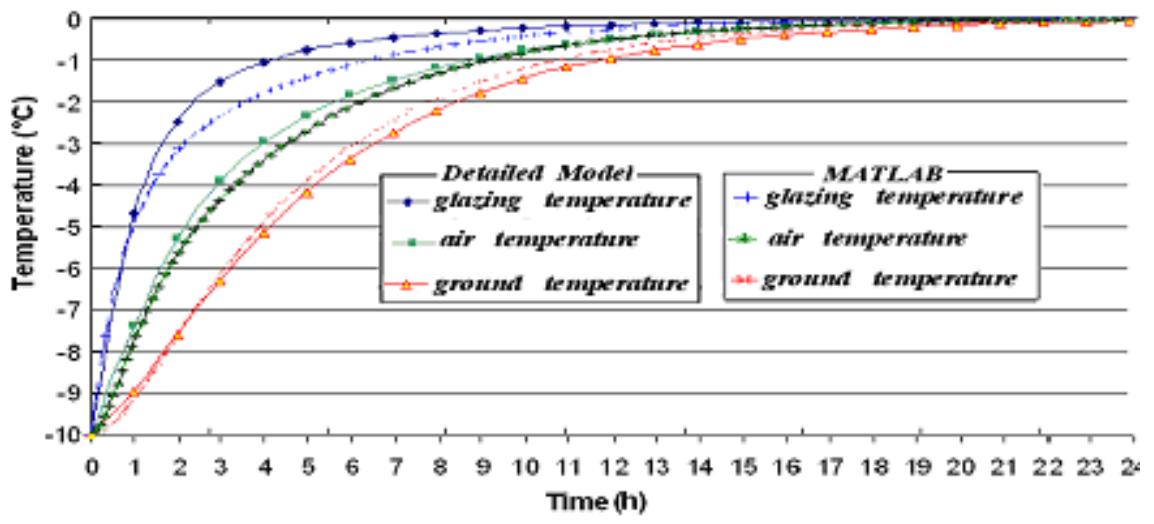

Figure 2: Variation of air temperature inside the dome following a step change of outdoor air temperature from $\left(-10^{\circ} \mathrm{C}\right)$ to $0^{\circ} \mathrm{C}$. Comparison between the detailed computer model and MATLAB solution to equations (12-14).

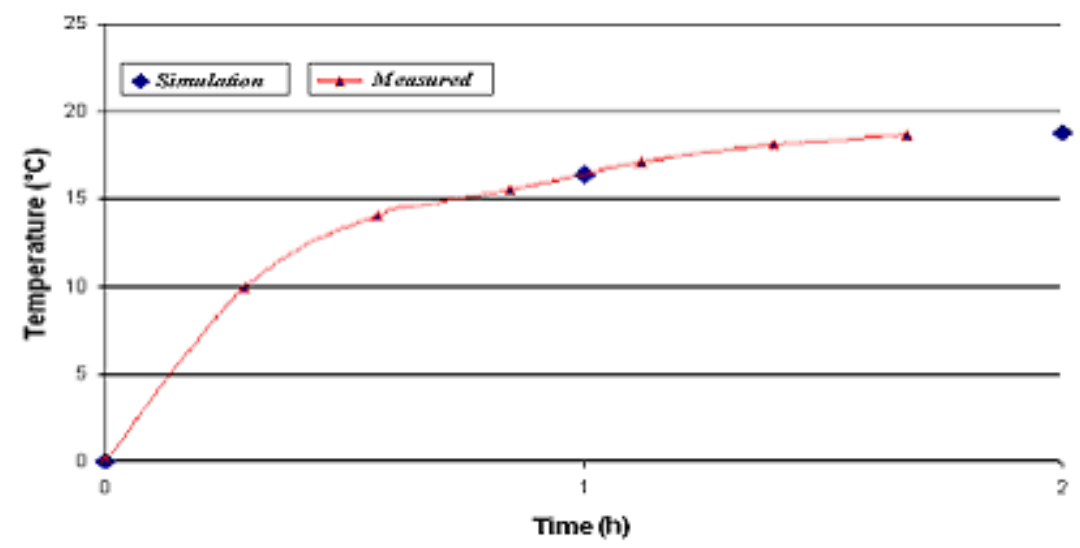

Figure 3: Variation of the glazing temperature following a step change of outdoor air temperature from $\left(0^{\circ} \mathrm{C}\right)$ to $19.25^{\circ} \mathrm{C}$. Simulated vs. measured [10].

\section{Case study}

A dome with radius of $20 \mathrm{~m}$, built around one house with the following dimensions $\mathrm{L}=10 \mathrm{~m}, \mathrm{~W}=10 \mathrm{~m}, \mathrm{H}=4 \mathrm{~m}$ is selected as a case study. The results are compared with a house unprotected by a dome.

The ground surface temperature and air temperature inside the dome, and the heating load of the house on February $21^{\text {st }}$, are shown in Figures 5 and 6 for the dome-covered house located in Yellowknife (Canada). This city is located at $61^{\circ} \mathrm{N}$ latitude, has the outdoor design temperature for heating of $-38^{\circ} \mathrm{C}$ and the annual number of heating degree days equal to $8256^{\circ} \mathrm{C}$. 


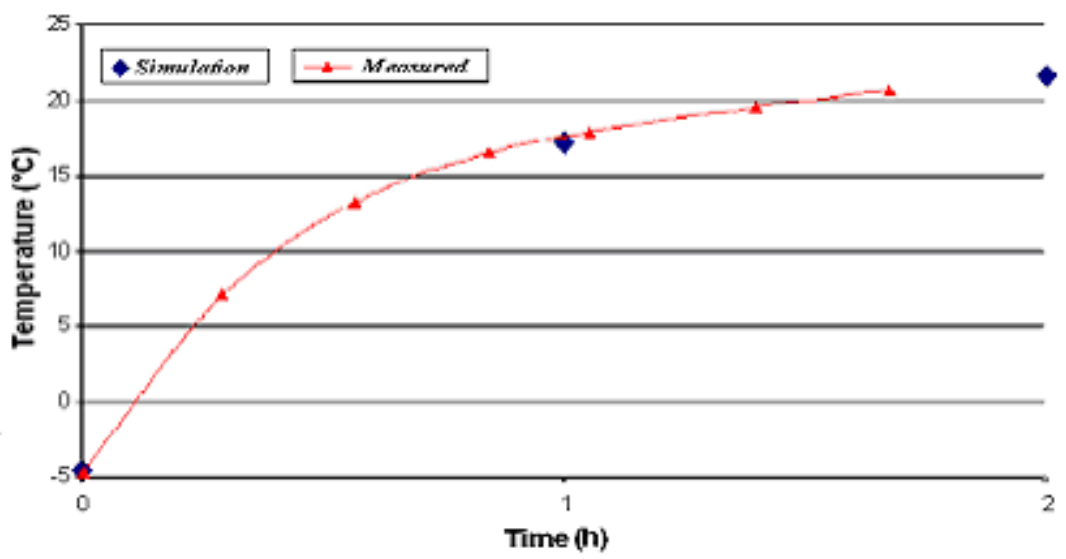

Figure 4: Variation of the glazing temperature following a step change of outdoor air temperature from $\left(-4.65^{\circ} \mathrm{C}\right)$ to $22.85^{\circ} \mathrm{C}$. Simulated vs. measured [10].

Simulation results show that the air temperature inside the dome can be lower than the outdoor air temperature at night (Figure 5), however, at 14:00 hours the air temperature inside the dome can be $12.4^{\circ} \mathrm{C}$ higher than the outdoor air temperature. Figure 6 shows a reduction of 34.9\% in heating load on February $21^{\text {st }}$. Table 2 compares the daily heating load of one house without and with a dome cover. It can be seen that during winter season, the dome helps to reduce the daily heating load of the house between $1.1 \%$ and $80.1 \%$. The annual average reduction of heating load is $19.1 \%$.

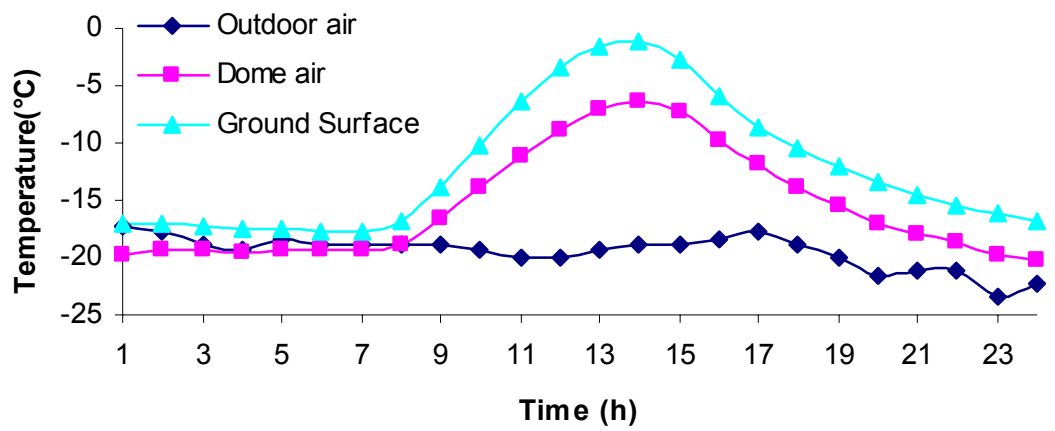

Figure 5: Air and ground temperatures inside the dome on February 21 versus the outdoor air temperature (Yellowknife). 


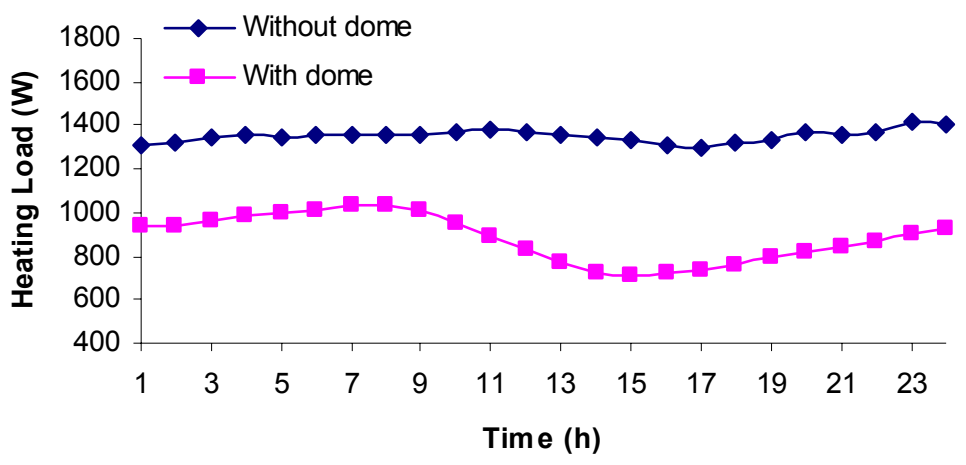

Figure 6: Hourly heating load on February 21 (Yellowknife).

Table 2: $\quad$ Daily heating load of the house, in kWh.

\begin{tabular}{cccc}
\hline Day & Without dome & With dome & Reduction (\%) \\
\hline Jan. 21 & 69.9 & 69.1 & 1.1 \\
Feb. 21 & 32.4 & 21.1 & 34.9 \\
Mar. 21 & 29.1 & 5.8 & 80.1 \\
Apr. 21 & 0 & 0 & - \\
May 21 & 0 & 0 & - \\
June 21 & 0 & 0 & - \\
July 21 & 0 & 0 & - \\
Aug. 21 & 0 & 0 & - \\
Sep. 21 & 0 & 0 & - \\
Oct. 21 & 0.14 & 0 & - \\
Nov. 21 & 50.2 & 45.4 & 9.6 \\
Dec. 21 & 49.4 & 45.5 & 7.9 \\
\hline
\end{tabular}

\section{Conclusion}

The simulation results predicted a reduction of about $19.1 \%$ of the annual heating load of a house when a dome is used compared with the case of an unprotected house. The development of zonal models to simulate the air temperature inside the dome is currently under way.

\section{Acknowledgement}

The authors acknowledge the financial support from Natural Sciences and Engineering Research Council of Canada. 


\section{References}

[1] Stach E. Form-optimizing processes in biological structures-selfgenerating structures in nature based on pneumatics. Design and Nature II, M.W. Collins \& C.A. Brebia (Editors). WIT Press, pp. 3-14, 2004.

[2] Arslan S. and Sorguc A. G. Similarities between "structures in natures" and "man-made structures": biomimesis in architecture. Design and Nature II, Collins M.W. \& Brebia C.A. (Editors). WIT Press, pp. 45-54, 2004.

[3] Croome, D.J. Covered Northern Township. International Journal of Ambient Energy, 6(4): 171-186, 1985.

[4] http://www.bfi.org/domes/.

[5] http://www.monolithicdome.com/.

[6] IESNA. Lighting Handbook, Reference and Application Volume. New York: Illuminating Engineering Society of North America, 2000.

[7] Wilkinson M. A. Natural Lighting under Translucent Domes. Lighting Research Technology, 24 (3), pp. 117-126, 1992.

[8] Laouadi A. \& Atif M.R. Transparent domed Skylights: Optical Model for Predicting Transmittance, Absorptance and Reflectance. Lighting Research and Technology, 30(3), pp. 111-118, 1998.

[9] Laouadi A. \& Atif M.R. Predicting optical and thermal characteristics of transparent single-glazed domed Skylights. ASHRAE Transactions, 105(2), pp. 325-333, 1999.

[10] Smith A. M. Prediction and Measurement of Thermal Exchanges within Pyranometers. MS Thesis. Virginia Polytechnic Institute, 1999.

[11] Porta-Gándara M.A. \& Gómez-Muñoz V. Solar performance of an electrochromic geodesic dome roof. Energy, 30(13), pp. 2474-2486, 2005.

[12] http://www.eere.energy.gov/buildings/energyplus/cfm/weather_data3.cfm/

[13] ASHRAE. ASHRAE Handbook Fundamentals, Chapter 3, Heat Transfer. Atlanta, 1993.

[14] Yazdanian, M. and Klems, J. Measurement of the Exterior Convective Film Coefficient for Windows in Low-Rise Buildings. ASHRAE Transactions, 100(1), pp. 1087-1096, 1994.

[15] Hottel H.C. and Sarofim A. F. Radiative Transfer. McGraw-Hill Book Company, 1967. 